Covered in INDEX COPERNICUS, IDEEAS. REPEC, SOCIONET, ECONPAPER, CEEOL

2017, Issue 19, pages: 89-104 | doi: https://doi.org/10.18662/upasw/05

\section{Psychosocial \\ Dimensions of \\ Family Violence}

[Dimensiuni psihosociale ale

puterii în organizație]

\section{Anişoara SANDOVICI ${ }^{1}$, Viorel ROBU ${ }^{2}$}

${ }^{1}$ Conferențiar universitar doctor, Universitatea „Vasile Alecsandri” din Bacău, Facultatea de Ştiințe ale Mişcării, Sportului şi Sănătății, E-mail:

anasandovici@yahoo.com

${ }^{2}$ Lector universitar doctor, Universitatea „Vasile Alecsandri” din Bacău, Facultatea de Litere, E-mail:

robuviorel upa@yahoo.com

\begin{abstract}
The common dictionary definition of violence states that this term encompasses the exertion of physical force so as to injure or abuse someone else. The inclusion of "abuse" in the definition is important, because it opens up the issues of force being used to induce negative psychological states and to violate basic human dignity and rights. One type of violence that has received increased attention in recent years is family violence, a deviant or delinquent behavior for which statistics are difficult to compile because it is so heavily underreported. The issue of family violence is an important area of public, political, and academic concern that goes to the heart of the institution of the family and marriage. At the individual level, it involves personal negative attitudes and aggressive behaviors as well as physical and emotional prejudices. There are a number of well-documented predictive factors of family violence, most of them psychological. Several forms of the family violencebased victimization have been described. Direct (as victim) or indirect (as eyewitness) exposure to family violence can have a significant psychological impact on children and adults during their development. For example, infants, school-age children and adolescents who witness violence in their homes are more vulnerable to excessive irritability, immature behaviors, sleep disturbances, emotional distress, fears of being alone, and developmental regression. This paper briefly analyses the causes, types and consequences of family violence.
\end{abstract}

Keywords: family violence; causes; types; consequences.

How to cite: Sandovici, A., \& Robu, V. (2017).

Psychosocial Dimensions of Family Violence. Anuarul Universitatii "Petre Andrei" din lasi, Fascicula: Asistenta Sociala, Sociologie, Psihologie, 19, 89-104. https://doi.org/10.18662/upasw/05 


\section{Introducere}

În literatura din domeniul ştiințelor comportamentale, precum şi în cea care se preocupă de aspectele socio-culturale ale dezvoltării umane, conceptul referitor la violență descrie o conduită agresivă acută care constă în utilizarea brutală, abuzivă şi injustă a forței sau a puterii, în vederea rănirii emoționale, vătămării fizice sau distrugerii unei alte persoane sau a unui grup de persoane, prin constrângere şi teroare emoțională, maltratare fizică, viol, omucidere, precum şi prin alte forme de agresivitate malignă (Postel, 1998; Strickland, 2001). Această definiție trimite mai mult către aspectele legale referitoare la actele de violență.

Termenul referitor la violență poate fi utilizat în două accepțiuni: una foarte restrânsă - utilizarea sau amenințarea cu folosirea forței fizice împotriva victimei sau a victimelor şi o doua, mai largă - orice formă de molestare fizică, sexuală sau emoțională sau de hărțuire, care conduce la efecte negative în planul stării de sănătate fizică şi psihică a victimei (Hearn, 1998). Intr-un sens larg, violența include toate conduitele agresive pe care un individ mai puternic din punct de vedere fizic, emoțional sau moral le manifestă în raport cu un alt individ mai slab: tratamente condamnabile moral şi penal la care sunt supuşi copiii maltratați, brutalizări fizice ale partenerului de viaţă (de exemplu, sindromul femeilor bătute de către soți) sau acte violente cu implicații penale, precum violul sau omorul (Postel, 1998). Prin extensie, actele violente pot însoți alte manifestări delincvente, precum tâlhăria. Accepțiunile termenului invocă faptul că gravitatea manifestărilor atitudinale şi comportamentale violente depinde mai puţin de natura lor intrinsecă şi mai mult de efectele pe care le au asupra stării de sănătate şi a celei de bine a victimei. De asemenea, violența nu acoperă aceeaşi sferă conceptuală cu termenul referitor la agresivitate, motiv pentru care cei doi termeni nu pot fi utilizaţi interşanjabil. Astfel, agresivitatea se referă la tendinţa unui individ de a ataca un alt individ sau orice alt obiect susceptibil de a constitui un obstacol în calea obținerii unei satisfacții imediate (Didier, 1998). Această tendinţă poate rămâne latentă (neexprimată printr-un act comportamental efectiv), iar acest fapt reprezintă un element cheie pentru diferențierea dintre violență şi agresivitate.

O formă de manifestare a violenței care, în ultimii ani, a atras din ce în ce mai mult atenția cercetătorilor şi a profesioniştilor din domeniul asistenței sociale, psihologice şi psihiatrice este violența familială. Este vorba despre un ansamblu de comportamente deviante şi, în multe cazuri, delincvente (care atrag sancțiuni penale), care nu se reflectă acurat în statisticile oficiale, deoarece victimile subraportează astfel de incidente. 
Violența familială (termen pe care îl preferăm în locul celui de violență domestică sau violență conjugală, pentru a include în sfera victimelor şi copiii crescuți într-o familie) acoperă o problematică importantă care se află în atenția autorităţilor publice şi politice, precum şi a cercetătorilor, prin implicațiile pe care le are pentru sănătatea familiei şi a mariajului - două dintre instituțiile sociale care se confruntă, in ultimele decenii, cu transformări majore. Sfera conceptului include atât domeniul vieții publice, cât şi cel al vieții private a unei familii sau a unui cuplu, la care se adaugă implicațiile pentru instituțiile sociale, politice şi economice.

Pentru abuzatori şi victime, violența familială implică o paletă complexă de atitudini negative şi comportamente agresive, precum şi prejudicii fizice şi psihice. Au fost identificați mai mulți factori predictivi în raport cu violența familială, mulți dintre ei de natură psihologică. De asemenea, au fost descrise mai multe forme de victimizare prin violență intrafamilială. Expunerea directă (ca victimă) sau indirectă (ca martor ocular) la incidente de violenţă familială poate avea un impact psihologic semnificativ asupra dezvoltării copiilor şi adulților, uneori pe toată durata vieții. De exemplu, copiii mici, cei de vârstă şcolară sau adolescenții care sunt martori la scene de violenţă intrafamilială sau comunitară se află într-un risc mai ridicat de a experimenta iritabilitatea excesivă, comportamente imature, tulburări ale somnului, distresul emoțional, teama de a nu rămâne singuri sau regresia în dezvoltare (Hughes şi Graham-Bermann, 1998; Osofsky, 1999; Rossman, Hughes şi Rosenberg, 2000). Această lucrare analizează, pe scurt, cauzele, formele de manifestare şi consecințele psihologice ale violenței familiale.

\section{Violența familială. Aspecte generale}

Violența manifestată în familie (denumită, uneori, prin termenul violenţă intrafamilială) însumează totalitatea actelor violente săvârşite de persoane angajate într-un rol marital, parental, sexual sau de îngrijire acordată altor persoane (Dobash şi Dobash, 1979). Pe scurt, este vorba despre orice formă de abuz fizic, sexual, emoțional sau economic care are loc în contextul unei relații conjugale sau în cel al relațiilor dintre părinți şi copii (Horne şi Levitt, 2006). Într-un sens mai larg, violența familială include toate actele de cruzime fizică sau emoțională, de la ameninţări şi admonestări, pălmuiri şi bătăi până la lovituri cauzatoare de moarte, sufocare, ştrangulare, tentativă de omor sau omor. Folosit în acest sens, termenul include şi actele de violenţă care se consumă în relațiile dintre rude (de exemplu, între unchi 
şi nepoți sau între veri), precum şi abuzurile comise asupra membrilor mai în vârstă ai unei familii sau asupra copiilor de către părinții lor.

Violența manifestată în familie se înscrie în sfera largă a actelor deviante şi, într-un sens mai restrâns (prin implicațiile penale), a celor delincvente. În România, amploarea şi gravitatea actelor de violenţă familială s-au accentuat, motiv pentru care numeroase foruri publice şi organizații non-guvernamentale au clamat necesitatea imperioasă a unor măsuri legislative şi instituţionale, menite, pe de o parte, să limiteze fenomenul, prin măsuri punitive faţă de agresori, iar pe de altă parte, să vină în sprijinul victimelor, îndeosebi copii şi femei (subpopulațiile cele mai vulnerabile). Prin urmare, potrivit Legii nr. 217/2003, violența familială este definită ca „orice acțiune fizică sau verbală săvârşită cu intenție de către un membru de familie împotriva altui membru al aceleeaşi familii, care provoacă o suferință fizică, psihică, sexuală sau un prejudiciu material." (Art. 2, alin.1). In virtutea acestei definiții, în categoria actelor de violență familială, au fost incluse: admonestarea, bătaia, atacul armat, amenințările verbale cu bătaie sau cu interzicerea unor libertăţi şi impunerea unor interdicții, sechestrarea şi amenințarea cu forța fizică, hărțuirea sexuală între soți sau hărțuirea exercitată de către un părinte asupra unui copil, violul etc. În sensul actului normativ de care discutăm, au fost incluse în categoria actelor de violenţă manifestată în familie şi acțiunile orientate către împiedicarea femeii de a-şi exercita drepturile şi libertățile fundamentale (de exemplu, dreptul de a avea o slujbă, de a-şi exprima propriile opinii, de a se ocupa de îngrijirea şi creşterea copiilor sau de îngrijirea propriei persoane etc.). De asemenea, în Legea nr. 217/2003, se precizează (Art. 3) că membrul de familie care se angajează într-un act violent este reprezentat de soț/soție, respectiv de către orice rudă apropiată (membru al unei familii care locuieşte şi gospodăreşte împreună cu făptuitorul actului violent - atât ascendenți reprezentați de părinții partenerilor conjugali, cât şi descendenți reprezentați de copii naturali sau adoptaţi).

\section{Cauze ale violenței familiale}

Deşi familia trebuie să constituie un mediu securizant pentru copii şi adolescenți, deseori, aceștia sunt victimizați prin diferite forme de abuz: emoţional, fizic sau sexual. De asemenea, multe femei (în acelaşi timp, soţii şi mame) cad victime bătăilor şi maltratărilor emoționale din partea soţilor, de multe ori, actele consumându-se chiar sub privirile neputiincioase ale copiilor. Factorii care favorizează declanşarea şi escaladarea actelor violente, în care unii membri ai unei familii se angajează şi cărora le cad victime ceilalţi 
membri includ: promiscuitatea fizică, economică şi morală din unele medii familiale (de exemplu, familiile în care sărăcia este o constantă sau cele în care unul dintre adulți este alcoolic sau ambii sunt dependenți de consumul de alcool), modelele parentale abuzive, situaţiile dificile pe care le întâmpină familiile monoparentale (de exemplu, mamele singure care întâmpină greutăţi materiale), nivelul redus al educaţiei părinţilor şi absenţa unei perspective sociale şi economice, ignorarea (sau tăinuirea) abuzurilor de către abuzatori şi victime, precaritatea stării de sănătate mintală a membrilor familiei (boli psihice sau consum de droguri) ş.a.

Fenomenul violenţei familiale este reprezentativ pentru mediile familiale caracterizate prin privarea social-economică (şomajul sau dificultăţile în găsirea unui loc de muncă, care conduc la probleme materiale şi la sărăcie), dar se manifestă şi în contexte familiale caracterizate prin (Spânu, 1998): comportamente şi reacții necontrolate, expectanțe nerealiste din partea părinților (sau în rândul partenerilor conjugali), tendințe de izolare socială, atitudini orientate către blamarea reciprocă (a părinților de către copii şi invers sau între soți), utilizarea intimidării şi a forței în relațiile sexuale dintre partenerii conjugali, stiluri duale ale personalităţii membrilor familiei, culturi bazate pe admonestări verbal, violenţă fizică sau teroare emoțională.

Multe dintre actele violente din unele cămine familiale (abuzuri comise asupra copiilor sau violentarea femeilor de către partenerii conjugali) au loc pe fondul consumului abuziv de alcool. Alcoolismul este o boală ascunsă. Virtualmente, nimeni nu ştie cu adevărat amploarea dramelor care se consumă în căminele în care alcoolul îl transformă periodic pe titularul familiei într-o persoană iresponsabilă: de la simpla perturbare a somnului de noapte până la abuzul sexual comis asupra copilului de către părintele al cărui câmp de conştiinţă este obnubilat prin efectele alcoolului. Numărul cazurilor de alcoolism vizibile în societate este comparabil cu minusculul vârf aparent al unui ghețar plutitor (Driga şi Robu, 2005).

În literatura centrată pe problematica alcoolismului, se foloseşte termenul referitor la codependență, pentru a se desemna ansamblul suferinţelor şi al modificărilor emoționale şi sociale pe care uzul excesiv de alcool le provoacă membrilor familiei alcoolicului şi altor persoane apropriate acestuia, precum prieteni sau colegi de muncă (Driga şi Robu, 2005). Este important de ştiut că negarea realității (după ce alcoolicul începe să perceapă faptul că depinde de băutură, tinde să refuze această realitate) este prezentă, într-o mare măsură, şi la codependenți. Partenerul de viaţă al unui alcoolic tinde să nege suferința din familie față de persoanele din afara acesteia şi induce consemnul secretului şi copiilor. Prin urmare, aceştia suferă, dar nu se confesează. Alcoolismul este o boală de familie. Cea mai 
mare parte a cuplurilor maritale afectate de alcoolismul unuia sau al ambilor parteneri este caracterizată prin: a) comportamente neadaptate contextelor intra- şi extrafamiliale şi exacerbarea trăsăturilor egofile; b) tendinţe de impunere de către alcoolic a controlului asupra partenerului de viaţă; c) neconcordanța dintre imaginea reală şi cea ideală a partenerului de viaţă; d) labilitatea emoțională care conduce la reacții violente față de partenerul de viaţă şi faţă de copii; e) pattern-uri disfuncţionale de comunicare şi de rezolvare a problemelor familiale. In acest sens, potențialitatea heteroagresivă a bărbaților consumatori de alcool se caracterizează prin faptul că unii dintre aceştia trăiesc intempestiv stări de furie şi agitaţie, care pot ajunge până la acte extrem de violente. În acest ciclu patologic, partenera de viață poate potența sau provoca actele violente. Soția poate întreține, conştient sau nu, tensiunea emoțională şi cognitivă a soțului care, pe fondul îngustării câmpului conştiinței şi a scăderii responsabilității pentru propriile comportamente şi faţă de ceilalți, trece la exteriorizarea tensiunilor pe care le resimte. Aşadar, iritabilitatea soțului conduce la conflictualitate (latentă) care, sub acțiunea unei provocări active sau pasive, se transformă în tensiune cu potențial exploziv, iar de aici până la actul agresiv acut mai este un pas.

Suferința codependenților maturi ai unui alcoolic este grea, dar efectele produse asupra codependenților copii sunt, de multe ori, devastatoare. Alcoolismul unuia sau al ambilor părinţi le afectează unora dintre copii condiţiile fundamentale pentru creştere şi maturizare, educaţia, sistemele de valori (prin lipsa unui model patern sau matern consistent, a cărui importanţă în dezvoltarea psihosexuală şi socială a unui copil a fost subliniată în repetate rânduri) şi, ceea ce este foarte grav, sănătatea mintală pentru întreaga viață. Dependența de alcool îl face pe părintele consumator să nu mai fie capabil să-şi îndeplinească rolurile uzuale, care sunt acreditate de societate pentru un părinte responsabil. Acesta nu se mai poate ocupa în mod normal de educația pe termen lung a copiilor, precum şi de îngrijirea de zi cu zi a acestora. Părintele băutor sau părinții băutori nu mai reprezintă o garanție pentru viitorul copiilor. Modelele educaționale sunt compromise, iar stabilitatea familiei este ameninţată (Driga şi Robu, 2005). De multe ori, suferinţa poate conduce la redutabile complicații în rândul copiilor şi al adolescenților, cum sunt dezvoltările patologice reactive ale personalității sau dezvoltările comportamentale dezadaptative (conduite agresive sau infracționalitate).

Cercetătorii au ajuns la concluzia că doar o abordare heteroclită poate conduce la clarificarea cauzelor şi a resurselor (personale, familiale şi extrafamiliale - de exemplu, suportul din partea rețelelor sociale) implicate în producerea, escaladarea şi ameliorarea violenței familiale (Bainter, 2002). În 
această abordare, se pune accentul pe natura multicauzală a actelor violente consumate în căminele familiale şi pe interacțiunile dinamice dintre o serie de variabile socio-economice (de exemplu, nivelul scăzut al educaţiei sau promiscuitatea materială), psihologice (de exemplu, anumite caracteristici individuale care constituie variabile vulnerabilizante în raport cu victimizarea prin violenţă domestică), socio-culturale (de exemplu, acceptarea şi promovarea culturii relațiilor intrafamiliale violente de către membrii familiei sau apărarea ideii potrivit căreia familia este o entitate privată, în care nimeni nu trebuie să se amestece) şi situaționale (de exemplu, dificultăţile care apar în creşterea şi dezvoltarea copiilor, evenimentele familiale neaşteptate sau evenimentele care joacă un rol precipitant în raport cu manifestările violente).

\section{Forme de manifestare a violenței familiale}

Printre formele în care se manifestă violența familială, se includ diferitele tipuri de abuz comise asupra soției/soțului, asupra copiilor sau asupra persoanelor în vârstă din familia extinsă. Violența manifestată asupra soției sau asupra soțului (domeniu neglijat în literatura centrată pe problematica violenței domestice - Hines şi Malley-Morrison, 2001) presupune exercitarea unei forme de abuz fizic, emoțional, sexual sau economic, în scopul perpetuării intimidării, puterii şi controlului. Soţiile sunt mult mai predispuse în raport cu victimizarea prin violenţă de către soții lor, datorită particularităților bio-constituționale şi psiho-comportamentale (Mitrofan, 1997). Prin tradiție, feminitatea desemnează o serie de trăsături de personalitate specifice: sensibilitate, finețe, preocupări pentru frumos, emotivitate, inteligență analitică etc. Însă, tot prin tradiție, imaginea femeii în raport cu cea a bărbatului a fost devalorizată, mai ales în unele țări ale lumii, în care ideologia religioasă joacă un rol foarte important în formarea perceptiiilor, a reprezentărilor sociale şi a atitudinilor faţă de femei. În unele părți ale lumii, bărbaţii căsătoriți au drepturi depline asupra soțiilor, inclusiv cele care permit aplicarea sancțiunilor bazate pe agresiunile fizice şi violență. De-a lungul istoriei, femeile au fost nevoite să suporte diverse forme de umilire, desconsiderare şi maltratare - iar toate acestea ca urmare a unor norme şi practici socio-culturale acceptate şi promovate în grupurile sau macrogrupurile de apartenență (este vorba despre aşa-numita violenţă structurală care are un fundament cultural-ideologic).

Abuzul şi violenţa manifestate de către părinţi asupra copiilor implică admonestări sau tentative de viol, abuzuri sexuale deschise sau mascate, bătăi repetate, ameninţări şi denigrări practicate, adesea, în scop de disciplinare. 
Disciplinarea copilului de către părinți constă în stabilirea unui sistem de valori, prin care copilul este ajutat să discearnă între bine şi rău, este obişnuit să gândească înainte de a acționa, este învățat să relaționeze cu alți copii şi cu adulţii într-un mod asertiv (non-agresiv şi non-conflictual), este stimulat să conştientizeze diversele pericole care i-ar putea afecta echilibrul fizic şi mintal şi să aplice strategiile de evitare/prevenire a acestora, este deprins cu autocontrolul impulsurilor şi al reacțiilor dezadaptative (Bădărău şi Lăzărescu, 2006). Insă, în viziunea greşită a unor părinţi, disciplinarea trebuie să aibă la bază dominarea, inducerea fricii şi culpabilizarea care sunt privite ca mijloace prin care copilul este constrâns să se supună. De asemenea, pedeapsa presupune exercitarea unui control prin forță asupra copiilor, cu scopul de a le modifica un comportament problematic. Deseori, astfel de părinți confundă disciplinarea copilului cu acțiunea de pedepsire. Ceea ce nu ştiu este că disciplinarea reprezintă o experiență de învățare care poate fi percepută de către copil ca fiind dificilă, incomodă sau chiar dureroasă.

Bătaia reprezintă o metodă disciplinară/educativă care a generat diferite atitudini, de cele mai multe ori contrare. Dacă pentru unii părinți „Bătaia este ruptă din rai !’'(este vorba, aici, despre un vechi principiu pedagogic perimat), pentru alții aceasta este inadmisibilă. Undeva, la mijloc, se află părinții pentru care folosirea rațională a bătăii - ca metodă disciplinară - este indicată, dar abuzul acesteia devine o contraindicație educațională. Nici ultima atitudine nu este cea mai adecvată, deşi unii dintre părinţi tind să o îmbrățişeze.

Unii autori au evidențiat şi au sintetizat trăsăturile particulare ale grupurilor de părinţi care folosesc bătaia ca mijloc de pedepsire şi disciplinare, dar care, în cele din urmă, devin agresori ai propriilor copii. Astfel, E. Merrill (citat de Mitrofan, 1996) a propus o tipologizare a părinţilor abuzivi în utilizarea agresiunii fizice (bătăii) în disciplinarea copiilor, tipologizare care a influențat alte încercări ulterioare:

$\checkmark$ Tipul I include părinți care se caracterizează printr-un nivel ridicat al agresivităţii care este manifestată continuu, uneori fiind clar concentrată şi focalizată, alteori nu. Supărările şi tensiunile nervoase le scapă controlului, uneori fiind nevoie de o acțiune stimulativă sau iritativă minimală, pentru a se declanşa reacția agresivă. Explicaţia unei asemenea conduite vizează, în principal, propriile lor experiențe trăite în perioada copilăriei timpurii (când, probabil, au fost traumatizați de către părinții lor).

$\checkmark$ Tipul II se caracterizează prin faptul că părinții sunt rigizi, compulsivi, reci din punct de vedere afectiv şi, după modul în care procedează în interacțiunile cu proprii copii, pledează mai mult 
pentru propriile lor drepturi decât pentru cele ale copiilor. Îi resping pe copii şi sunt preocupați mai mult de propria lor plăcere.

$\checkmark$ Tipul III include părinţi care sunt persoane pasive şi dependente din punct de vedere emoțional şi social. Sunt oameni modeşti şi reticenți şi, totodată, şovăielnici în a-şi exprima sentimentele şi dorinţele. Aparent, nu sunt agresivi, dar, adesea, intră în competiție cu proprii copii, pentru a câştiga atenția partenerilor de viață, fiind, de obicei, depresivi, imaturi şi capricioşi.

$\checkmark \quad$ Tipul IV include părinți care sunt fie persoane frustrate încă din perioada tinereței, fie persoane inteligente, dar care au anumite dizabilităţi fizice ce îi împiedică să-şi sprijine propria familie. Este posibil ca astfel de părinți să stea acasă şi să aibă grijă de copii, în timp ce partenerii lor de viață să meargă la slujbă. În asemenea situații, gradul de frustrare al părintelui problematic conduce la pedepsirea severă a copiilor.

Violența comisă asupra bătrânilor include abuzul fizic, emoțional, neglijarea, abuzul financiar şi violarea drepturilor. Astfel de manifestări sunt îndreptate, în special, spre femeile vârstnice, mai ales spre cele aflate în suferinţă fizică sau emoțională şi sunt comise de către femei aflate între două vârste, de obicei fiice (Mitrofan, 1997). Faptul că femeile în vârstă sunt mai des victime ale abuzului din partea fiicelor s-ar putea datora şi duratei mai mari de viață în rândul femeilor, în comparație cu speranţa de viaţă în rândul bărbaților, iar faptul că agresorii sunt mai des femei s-ar putea datora relației dintre acestea şi victime, în contextul căreia agresoarele sunt însărcinate cu îngrijirea victimelor.

R. J. Gelles (1974) considera că, aşa cum există diferite forme de manifestare a abuzului, tot aşa există şi diferite sensuri atribuite incidentelor violente care au loc într-o familie. Autorul citat arată că violența familială trebuie explicată în funcție de sensurile pe care actorii implicați în scenele violente care se consumă într-un cămin familial le atribuie actelor la care asistă. Din acest punct de vedere, Gelles (1974) deosebeşte între: violența „normală”, violenţa secundară, violența vulcanică, violența asociată abuzului de alcool, violența reactivă (cu sens de autoprotecție), violența cu sens unic şi violenţa asociată relațiilor sexuale şi geloziei.

Violența „normală” constituie acea formă de manifestare a violenței familiale care este acceptată, aprobată şi chiar mandatată în contextul interacţiunilor familiale. Părinţii şi normele culturale au în vedere faptul că „Bătaia este ruptă din rai !”, iar partenerii conjugali consideră că este acceptabil şi normal ca bărbatul să-şi lovească soția. Din punctul de vedere al victimei, violența partenerului de viaţă este „normală”, întrucât contribuie, în 
mod essential, la atingerea unui scop (Gelles, 1974). Victimele violentate în familie (soțiile abuzate de către soți) consideră episoadele de agresiune ca fiind acceptabile, deoarece merită să fie lovite şi denigrate. Violența „normală” se manifestă cu acordul tacit al membrilor familiei, indiferent de frecvența, intensitatea şi gravitatea consecințelor pe care le au episoadele violente. În ceea ce priveşte „violența normală” caracteristică relaţiilor dintre părinți şi copii sau adolescenți, cei din urmă (victimele) ajung să creadă că forța este necesară şi inevitabilă, în procesul de disciplinare şi de control pe care părinţii trebuie să îl exercite asupra copiilor. Copiii şi adolescenții justifică victimizarea în contextual căreia părinții sunt abuzatori nu prin violența abuzivă şi injustă, ci prin semnificațiile normative.

În contextul violenței secundare, manifestările părinților se intersectează cu victimizarea dintre partenerii conjugali (Gelles, 1974). Dinamica violenței secundare debutează cu utilizarea forței fizice de către părinți, victimele fiind copiii sau adolescenții. În timp ce părintele abuzator consideră acest lucru ca fiind normal şi legitim, celălalt părinte poate percepe actele violente ca fiind ilegitime. Neînțelegerile dintre părinți, în ceea ce priveşte modul de creştere şi de educare a copiilor, constituie surse de conflict conjugal. A doua etapă a dinamicii prin care apare şi se manifestă violența secundară implică intervenția unuia dintre părinți (cel frustrat), care se interpune între copilul victimizat şi părintele abuzator. Intervenţia se poate manifesta printr-un atac violent împotriva soțului/soției violent(e), astfel ajungându-se la escaladarea manifestărilor violente dintre membrii familiei.

Violența vulcanică este percepută de către victime ca fiind ilegitimă şi are loc atunci când nivelul stresului şi al frustrărilor atinge cote paroxiste (Gelles, 1974). Deoarece nivelul stresului sau al frustrării nu mai poate fi controlat, soțul sau soția „erupe” într-o reacție agresivă fie în plan verbal, fie în plan fizic sau în ambele. In relaţiile violente dintre părinţi şi copii, unele mame ajung să reacționeze în mod abuziv, datorită unui nivel scăzut al toleranței, coroborat cu probleme în ceea ce priveşte controlul impulsurilor de moment. Copilul victimizat poate percepe reacţia din partea părintelului abuzator sau a părinților abuzatori ca fiind ilegitimă şi poate experimenta simptomele specifice reacției de stres acut.

Violența asociată cu abuzul de alcool este foarte frecvent o caracteristică a comportamentului intrafamilial pe care îl manifestă bărbații. Numeroase studii de teren au subliniat asocierea semnificativă dintre frecvența scenelor de violență domestică şi abuzul de alcool din partea agresorilor bărbați (Gelles, 1974). Martorii la scenele violente consumate în căminul familial confirmă reprezentarea cu privire la faptul că alcoolul 
consumat în exces acționează ca un agent dezinhibitor, conducând la eliberarea impulsurilor şi a tensiunii psihice sub forma reacțiilor violente.

În schimb, violența care semnifică o reacție de autoprotecție este întâlnită mai des în cazul femeilor abuzate de către soți (Gelles, 1974). Manifestările violente iniţiate de către soțiile bătute sau admonestate pot avea loc fie în timpul sau în urma victimizării, fie cu sens de anticipare (soția declanşează un atac fizic sau verbal asupra soțului datorită fricii care însoțeşte gândul ca va fi iarăşi bătută).

Violența cu sens unic se manifestă atunci când soțiile abuzate fizic sau emoțional nu răspund în aceeaşi manieră (Gelles, 1974). Constrângerile care le determină să-şi înfrâneze pornirile sunt, adesea, de ordin pragmatic. Unele soții victimizate nu-şi lovesc soții, datorită fricii de a nu fi bătute şi mai tare. Ele cred că absența acestei „întăriri” va contribui la diminuarea conflictului deschis. Altele sunt puternic influențate de credința potrivit căreia un bărbat poate dispune oricând de nevastă, motiv pentru care o reacție din partea acesteia este de prisos. Pasivitatea şi sentimentul de neajutorare învățată sunt mecanismele care explică absența reacțiilor din partea unora dintre femeile victimizate de către soți.

Violenţa asociată cu relațiile sexuale şi cu gelozia dintre partenerii conjugali se explică prin pattern-urile defectuoase de comunicare pe marginea problemei infidelității, care se instalează în multe diade conjugale (Gelles, 1974). Unele reacții violente din partea soților geloşi se explică prin antecedentele soției în materie de flirturi sau relaţii sexuale extramaritale.

Aşadar, violența familială variază în funcție de contextul în care se manifestă, de semnificaţiile pe care membrii familiei le atribuie episoadelor violente, precum şi de justificările pe care partenerii conjugali le aduc pentru propriile lor manifestări agresive. Cu toate că poate fi descrisă o tipologie generoasă, în ceea ce priveşte manifestările agresive şi violente consumate într-un cămin familial, violența familială constituie un fenomen unitar (Gelles, 1974). Indiferent de forma în care se manifestă, efectele negative ale violenței familiale sunt, adesea, foarte traumatizante şi apar de timpuriu. Ele se perpetuează în timp, nu numai în planul funcționării victimei sau a victimelor, ci şi asupra agresorilor. De aceea, este foarte importantă descoperirea surselor care declanşează şi alimentează episoadele de violenţă familială, surse care trebuie relaţionate cu structura socială a familiei, cu pattern-urile de comunicare, comportament şi rezolvare a problemelor, precum şi cu întregul complex de norme, valori, tradiții, obiceiuri, credințe şi reprezentări sociale referitoare la căsătorie, familie şi la creşterea şi educarea copiilor. 


\section{Consecințe ale violenței familiale}

Impactul pe care violența familială îl are asupra victimelor variază în funcție de tipul de violență şi de intensitatea actelor (Bainter, 2002). Victimele pot avea nevoie de îngrijiri medicale pentru vătămări corporale (de multe ori, severe). În multe cazuri, victimele (copii sau adulți) decedează, ca urmare a severității rănilor produse printr-un atac fizic. Problemele emoționale (precum anxietatea sau depresia) reprezintă aproape o constantă a travaliului psihologic pe care victimele violenței familiale, indiferent de vârstă, îl experimentează (Cascardi, Langhinrichsen şi Vivian, 1992; Connelly, 2000; Stets şi Straus, 1990). Copiii care asistă, în mod repetat, la scene de violenţă consumate între părinţi sunt predispuşi către anxietate şi depresie, întâmpină dificultăţi în interacţiunile cu alți copii şi tind să manifeste, la rândul lor, comportamente agresive (Hughes şi GrahamBermann, 1998; Kashani şi Wesley, 1998; Rossman, Hughes şi Rosenberg, 2000). Rezultatele mai multor studii sugerează că expunerea copiilor la violență domestică (fie ca martori, fie ca victime) se asociază cu un risc mai ridicat pentru socializarea violentă a acestora, în sensul în care, în relațiile romantice de mai târziu, tind să experimenteze rolul de abuzator sau pe cel de victimă (Kashani şi Wesley, 1998). Totuşi, chiar dacă violenţa familială poate avea efecte serioase în domeniul stării de bine fizice şi emoționale a copiilor, nu toţi copiii expuşi la astfel de incidente sunt afectaţi în acelaşi grad. Studiile care s-au preocupat de impactul victimizării copiilor prin acte de violență familială s-au confruntat cu o limită metodologică, în sensul în care bazinul din care au fost recrutați participanții a fost reprezentat, în multe demersuri, de adăposturi pentru copiii abuzaţi fizic, emoţional sau sexual, care prezintă, de regulă, probleme emoționale severe (Bainter, 2002).

Construindu-şi expunerea pe studii de caz ale unor adolescenți şi tineri, P. Coman (2003) prezintă experiențele emoționale devastatoare şi eforturile de supraviețuire pe care le depun victimele abuzurilor parentale, în care admonestările, umilirile şi jignirile, afirmațiile devalorizatoare şi bătăile constituie o regulă, iar abuzul sexual este o experiență foarte traumatizantă. Autoarea arată că adolescenții şi copiii victime ale violenței familiale sunt protagoniştii unor încercări disperate de disimulare a traumelor pe care le trăiesc. În multe cazuri în care sunt pedepsiți (prin bătaie, maltratare sau abuz emoțional), copiii şi adolescenții neajutorați îşi asumă responsabilitatea şi vina pentru pedeapsa pe care o primesc din partea părintelului abuzator sau a părinţilor abuzatori. Prin educație, astfel de copiii şi adolescenți învață că nu pot gândi urât despre părinți şi nu au dreptul să li se opună, legitimând astfel abuzurile din partea părinţilor. Ca urmare, ajung la deteriorarea gravă a 
stimei de sine, la o imagine despre ei înşişi negativă şi autodevalorizatoare, experimentând sentimentul de inferioritate şi de neajutorare, care este condiționat de experiențele traumatizante pe care le trăiesc. Adesea disperați, copiii şi adolescenții care sunt victime ale violenței parentale devin din ce în ce mai puțin capabili şi dornici să încerce să schimbe ceva din situația traumatizantă în care se află. Atunci când nu li se interzice, în mod expres, acest lucru, sunt incapabili să exploreze lumea, devin inhibați în a căuta să opună rezistență abuzurilor care îi chinuie (de teamă să nu fie acuzaţi de destrămarea relaţiilor familiale), instalându-se apatia (deşi unii autori au arătat că această stare acționează, de fapt, ca un mecanism protectiv).

De obicei, copiii şi adolescenții abuzaţi emoţional, sexual sau fizic trăiesc un sentiment acut de teamă, care conduce la blocaj şi confuzie. Ei sunt confuzați în relațiile cu familia (eventual cu părintele care nu este abuzator, dacă această situație le este caracteristică), prietenii şi colegii de şcoală, profesorii, dar şi cu părintele agresor. Copilul sau adolescentul caută soluții „disperate” pentru a supraviețui, încercând, de cele mai multe ori, să se adapteze la relaţiile defectuoase din familie, mai ales la relaţiile cu părintele abuzator (Coman, 2003). Unii dintre ei devin dependenți de membrii familiei, inclusiv de părintele abuzator sau de părinții abuzatori (dezvoltând o formă de ataşament nesigur, de tip anxios) şi cred că merită să fie jigniţi, amenințați sau bătuți, negând drama iubirii condiționate pe care o trăiesc. Procesul este dinamic şi debutează prin orientarea victimelor către a fi din ce în ce mai mult de acord cu modelele cognitive, valorile şi cu pattern-urile de comportament ale părinteluie agresor sau ale părinților agresori, pe măsură ce depind de bunăvoinţa lui/lor. Însă, pierd în relaţiile cu ceilalți copii şi adolescenți, care sunt superficiale, instabile şi reci din punct de vedere afectiv. Relațiile sociale ale copiilor şi adolescenților care cad victime violenței familiale sunt egocentriste şi au scopul de apărare a propriei lor persoane. Sunt situații în care copiii şi adolescenții victimizați caută cu obstinație să imite comportamentul agresiv al părinţilor în relaţiile cu ceilalți (mai ales în cele cu alți copii sau adolescenți de aceeaşi vârstă). Violența manifestată de către părinții abuzatori în relaţie cu proprii copii conduce la dezvoltarea unor pattern-uri relaționale bazate pe şantaj emoţional, copiii sau adolescenții ajungând la resentimente, furie, mânie sau reacții explozive într-un cuvânt, la o serie de tulburări emoţionale care, mai târziu, în viaţa de adult, au repercursiuni grave. Sunt şi copii sau adolescenţi care opun în mod activ rezistenţă violenței şi abuzurilor la care sunt supuşi de către părinţi. Însă, acestora le sunt caracteristice un sistem valoric puternic şi bine conturat, la care se adaugă un model comportamental rezilient, în sensul în 
care descoperă alte forme de comportament parental, care sunt construite pe principiul comunicării deschise şi al întâmpinării nevoilor afective.

În încheierea lucrării sale, Coman (2003) notează foarte sugestiv pentru experiențele traumatizante pe care le trăiesc adolescenții abuzați de către părinți: „Adolescenții abuzați rămân (în cele mai multe dintre cazuri, dar sunt şi excepţii) dependenți emoţional, imaturi afectiv şi, dacă reuşesc să plece de lângă părinți, pot deveni dependenți de partenerul de viaţă (şi chiar să abuzeze de el). Ceea ce este grav este că adolescenții abuzați pot fi generația de mâine de părinți abuzivi: dependența afectivă învățată din relația cu părinții lor va fi transferată în relația cu proprii copii, aşa încât îi vor obliga să le satisfacă nevoile emoționale.” (p. 166).

\section{Implicații practice}

Foarte răspândit pe întregul mapamond, fenomenul violenței familiale implică o cauzalitate şi o dinamică complexe. T. Pirozynski, Gh. Scripcaru şi M. Berlescu (1996) arată că: „Violenţa domestică reprezintă o ultimă resursă în lipsa culturii şi a valorilor familiale. Prin tolerarea îndelungată a violenței, familia poate deveni o cale a vieții marcată de riscuri majore, cum ar fi delincvența la vârsta adultă, ceea ce face necesară o abordare multidisciplinară, pentru a stopa acest fenomen.” (p. 53).

Deşi, în România, există unele statistici şi studii cu privire la violenţa familială sau domestică, viaţa cotidiană şi mass-media reflectă, în continuare, o amplitudine îngrijorătoare a cazurilor de abuz care are loc între parteneri conjugali sau în relațiile dintre părinți şi copii. Studierea cauzelor, a caracteristicilor, precum şi a consecințelor actelor violente comise în căminele familiale este o întreprindere dificilă, dată fiind ,zidul” care înconjoară şi izolează de restul comunitătii multe dintre familiile care experimentează violența în interacțiunile dintre membri. De aceea, relevarea amplitudinii fenomenului violenței conjugale şi parentale reprezintă o provocare pentru sociologi, psihologi, asistenți sociali, pentru decidenții în materie de legislație penală, precum şi pentru profesioniştii care acordă servicii de asistenţă abuzatorilor şi victimelor acestora.

În efortul de prevenire şi combatere a victimizării copiilor şi adolescenților prin violență din partea părinţilor, trebuie să se pornească de la premisa că socializarea patologică a unui copil va conduce la blocaje în dezvoltarea ulterioară a personalității acestuia, în achiziția status-urilor şi a rolurilor pe care societatea şi comunitatea din care face parte le aşteaptă de la el. De exemplu, trebuie să fie intensificate programele destinate sensibilizării opiniei şi a conştiinței membrilor unei comunităţi în legătură cu beneficiile 
comunicării problemelor intrafamiliale şi solicitării ajutorului specializat, precum şi cu drepturile legale pe care le au membrii unei familii, indiferent de vârsta şi condiția medico-psiho-socială a acestora. De asemenea, utilitatea programelor care urmăresc suportul psihologic pentru victimele directe şi colaterale ale violenței familiale este bine documentată în literatura internațională.

Toate măsurile care urmăresc prevenirea violenței familiale şi asistarea din punct de vedere psihologic, social şi juridic a victimelor şi a abuzatorilor trebuie să fie integrate în programe mai largi de ajutor şi intervenție, care să vizeze ansamblul factorilor economici, sociali, psihologici şi culturali asociați riscului crescut de victimizare prin violență intrafamilială a copiilor, adolescenților şi a adulților. Trebuie reținut faptul că întârzierea în intervenția asupra cazurilor de copii, puberi sau de adolescenți care prezintă o istorie cronicizată a expunerii la diverse forme de violență şi abuz familial va produce complicați ulterioare greu de surmontat, care le pot anula şansa de a deveni ceea ce pot şi trebuie să devină.

\section{Bibliografie:}

Bainter, T. R. (2002). Domestic violence. In N. J. Salkind (Ed.), Child Development (pp. 124-127). New York: Macmillan Reference USA.

Bădărău, O. A., Lăzărescu, A. M. (2006). Pedeapsă-disciplinare-abuz asupra copilului. În Anuarul Universității „Petre Andrei” din Iaşi. Serie nonă (Tomul I, pp. 438-449). Iaşi: Institutul European.

Cascardi, M., Langhinrichsen, J., \& Vivian, D. (1992). Marital aggression: Impact, injury, and health correlates for husbands and wives. Archives of Internal Medicine, 152 (2), 1178-1184.

Coman, D.-P. (2003). Ce se întâmplă cu adolescenții abuzați? În I. Mitrofan (Coord.). Cursa cu obstacole a dezvoltării umane (pp. 161-166). Iaşi: Editura Polirom.

Connelly, E. R. (2000). Child Abuse and Neglect: Examining the Psychological Consequences. Philadelphia: Chelsea House.

Didier, B. (1998). Agresivitatea. În J. Postel (Coord.). Larousse. Dictionar de psibiatrie şi de psibopatologie clinică (trad., pp. 23-26). Bucureşti: Editura Univers Enciclopedic.

Dobash, R. E., \& Dobash R. (1979). Violence Against Wives. A Case Against the Patriarchy. New York: Free Press.

Driga, O., Robu, V. (2005). Date preliminare cu privire la incidența alcoolismului în familiile copiilor de vârstă şcolară medie din Municipiul Iaşi. Revista de Asistență Socială, 3-4, 70-78. 
Gelles, R. J. (1974). The Violent Home. A Study of Physical Aggression Between Husbands and Wives. Beverly Hills, CA: Sage Publications, Inc.

Hearn, J. (1998). The Violences of Men. London: Sage Publications, Ltd.

Hines, D. A., \& Malley-Morrison, K. (2001). Psychological effects of partner abuse against men: A neglected research area. Psychology of Men \& Masculinity, 2(2), 75-85.

Horne, S. G., \& Levitt, H. M. (2006). Domestic violence. In N. J. Salkind (Ed.), Encyclopedia of Human Development (pp. 390-392). Thousand Oaks, CA: Sage Publications, Inc.

Hughes, H. M., \& Graham-Bermann, S. A. (1998). Children of battered women: Impact of emotional abuse on adjustment and development. Journal of Emotional Abuse, 1(2), 23-50.

Kashani, J. H., \& Wesley, D. A. (1998). The Impact of Family Violence on Children and Adolescents. Thousand Oaks, CA: Sage.

Mitrofan, N. (1997). Victima şi victimologia. În N. Mitrofan (Coord.), V. Zdrenghea, T. Butoi. Psibologie judiciară (pp. 69-105). Bucureşti: Casa de Editură şi Presă ,Şansa” SRL.

Mitrofan, N. (1996). Agresivitatea. In A. Neculau (Coord.). Psibologie socială. Aspecte contemporane (pp. 433-443). Iaşi: Editura Polirom.

Osofsky, J. D. (1999). The impact of violence on children. The Future of Children, 9(3), 33-49.

Pirozynski, T., Scripcaru Gh., Berlescu, M. E. (1996). Psihopatologie relatională. Iaşi: Editura Junimea.

Postel, J. (1998). Violență. În J. Postel (Coord.). Larousse. Dicționar de psibiatrie si de psibopatologie clinică (trad., pp. 603-604). Bucureşti: Editura Univers Enciclopedic.

Rossman, B. B. R., Hughes, H. M., \& Rosenberg, M. S. (2000). Children in Violent Families: The Impact of Exposure. Washington, DC: Taylor \& Francis.

Spânu, M. (1998). Introducere în asistențta socială a familiei și protecția copilului. Chişinău: Editura Tehnică.

Stets, J. E., \& Straus, M. A. (1990). Gender differences in reporting marital violence and its medical and psychological consequences. In M. A. Straus \& R. J. Gelles (Eds.), Physical Violence in American Families: Risk Factors and Adaptations to Violence in 8,145 families (pp. 151-166). New Brunswick, NJ: Transaction.

Strickland, B. R. (2001). Violence. In B. R. Strickland (Executive Editor), The Gale Encyclopedia of Psychology (2nd ed., pp. 656-658). Farmington Hills, MI: Gale Group.

Legea nr. 217/2003 publicată în M.O. nr. 367 din 29 mai 2003. 